Joseph Ezra Bigio*

\title{
Reforming the European Scene
}

Submitted: August $7^{\text {th }}, 2010$

Accepted: September $16^{\text {th }}, 2010$

\section{Summary}

An unbridled globalization based on a simple premise about earnings and profit may be detrimental to the livelihood of many thousands of individuals. The greed and utter selfishness that result from the adherence to this sort of business practice are the two things that generate more unemployment, misery and degradation than most other characteristics of the human species.

These considerations present the challenge for Western societies and call for the implementation of other principles, standards and procedures, such as cooperation, cohesion, development objectives and social responsibility. In the first part of the paper this approach is tested in the case of the EU-US foreign exchange relationships. The second part of the paper raises more general and fundamental issues. While adhering to the Schumpeter-type innovation environment, it aims to introduce the social dimension ahead of the immediate competitiveness and, therefore, argues for the fundamental reform of the catechism of the capitalist manager. The EU, due to its advanced integration, is relatively well-equipped to move towards the new economic system.

\section{Introduction}

This essay is an expanded and updated version of two earlier contributions delivered in the early 2000's (Bigio, 2000; Bigio, 2002). By now they could easily be regarded as having been overtaken by events, especially in the aftermath of the tragedy of September $11^{\text {th }} 2001$ and in the course of the global financial crisis 2007-2010. Even so, I have the

${ }^{*}$ The Honorary President of the Lisbon Civic Forum; Professor of Economics and Former Director of the Centre for Studies of Globalization (CEG), Universidade Autónoma de Lisboa (UAL). 
temerity to suggest that the hypothesized needs for an international cooperation as well as for an enhanced development perspective in economics and economic policy have become ever stronger.

The world has changed, irrevocably, in such ways that the very fabric of Western civilization could unravel. Perhaps we should note, however, how rapidly the Vice-Chairman of the Federal Reserve moved to secure international money markets very, very soon after the attacks on the World Trade Center and the Pentagon, while Mr. Greenspan was out of the United States. Along with several other methods of ensuring liquidity, a by previous standards enormous currency swap of around $€ 770$ billion was enabled by the ECB and the Federal Reserve without the least hesitation. The need for instant cooperation was clearly evident to everyone concerned. That was for the immediate emergency. What we have to remember is that, faced by the hatred of the nihilists of terror, from now on the component countries of Western Civilization will have to close ranks and cooperate on daily bases.

In parallel, the world has to perform under increasingly global markets, financial markets in particular. Globalization is becoming a very misused and misinterpreted term. For its detractors, it is synonymous with concerted aims to create hegemony for the U.S. dollar. It shouldn't be but the advocates of the absolute supremacy of the dollar tend to use the word this way. Those people who see through the pretence come to over-react. The result is destructive antagonism. This helps nobody, either in the short, medium or long term.

What does help is recognition of what globalization truly represents. In my view, it is the use of Foreign Direct Investment as a strategic tool for the acquisition of market share and, incidentally, industrial rationalization. As such it distinctly strengthens the economic muscle of the outwardly investing country even as it helps to develop the economy of the receiving nation. And it is practiced by many enterprises both in the U.S.A. and the European Union.

Beyond the EU-US perspective and beyond financial cooperation, it seems reasonable to discuss also the implications of globalization for management decisions, business practices and, more broadly, for their growth and development outcomes. Although we may presume that many people who subscribe to the objectivist philosophy of Ayn Rand think of globalization as a great boon, its economic outcome fails to qualify even for beatification (Rand, 1957). By contrast, for the last ten years or so, while all forms of greed have prevailed, the underlying scenario has started to change. The early shoots of what I call New Era Capital Management are beginning to break through. And the most recent financial crises give them impetus. It may be argued that the maxims of Milton Friedman and the 'Chicago' group of monetarists are much to blame for several financial crises. Not because of their monetary theories in general, which undoubtedly have their merits; but specifically because of their promotion of the tenet that corporate management has a prime duty to maximize profits. A shibboleth from which followed the demands of investment bankers and analysts for the maximization of shareholder values, even in the short term.

In mid-2001, as the world struggled to recover from the wave of financial crises of the late 1990's , in my view the way out lay through setting rigorous curbs on Mergers and Acquisitions based on large quantities of highly unwarranted bank finance. It seemed 
clear that the merits of the purported synergies and greater profits to be gained from joining together two different enterprises, each with its own business culture, were far too exaggerated. All the more so, when the plan B exit routes from the fancy financial engineering almost invariably implied the kind of restructuring that involves laying off around $20 \%$ of the skilled personnel. Simultaneously, an adherence to the simple premise about earnings and profits, with development and cooperation considerations in the shadow, did not help avoid further economic and financial turbulences, including the global crisis of 2007-2010.

\section{Contextual Background for the Euro and the US Dollar Relationship}

The relationship between the Euro and the U.S. Dollar reflected what had been happening as a result of the strategic taking of those very many cross border investment positions. Global flows of foreign direct investment were set to top $\$ 1,000$ billion during the year 2000 (UNCTAD, 2000). About $\$ 250$ billion of this flow was between the EU and the U.S.A. Despite promising prospects for the EU economy, European companies continued to invest so massively in M\&A deals with U.S. industries that the net balance of the flow has been around $\$ 84$ billion in favor of the dollar.

To compound the effect, much of the inward flow to the EU was not converted into Euros but retained in dollars. Thus, the net results in favor of the U.S. dollar were close to $\$ 167$ billion, without including another important factor. U.S. companies raised another $\$ 80$ billion via the Euro corporate bond market, which they promptly converted to dollars, bringing the total effect to around $\$ 247$ billion. This meant that virtually none of the FDI flows between the EU and the U.S.A. favored the Euro's rate of exchange.

It was these FDI flows that gave the Euro and the European Central Bank such a headache. Media and market perceptions were of secondary importance. And it was mainly because of the FDI flows that the U.S. Federal Reserve only had to raise interest rates quite modestly, in order to ensure that the annual auctions of treasury bonds would attract enough buyers to enable the U.S.A. once again to finance its huge current account deficit.

The world has continued to finance the development of the U.S. economy. Unless it did so, there would be a much more rapid collapse of the dollar than the world's financial markets could manage to survive. Also, by ensuring the continued development of the U.S. economy, other nations are insuring the prospects for businesses in their own country.

Allow me to stress that I do not support the idea of unbridled capitalism. The greed and utter selfishness that result from the adherence to that idea are, without any doubt at all, the things that generate more unemployment, misery and degradation than most other characteristics of the human species.

Even so, it does look as if I may mean that what has been good for the U.S.A. was necessarily good for the EU. This is not what I imply. What I would like to get across is the idea that monetary and financial activities in the EU and the U.S.A. are, of necessity, complementary. This not only cuts across the idea of confrontation between the EU and the U.S.A. It indicates the concept that dynamic economic cooperation will be more 
beneficial for both. And using cooperative approaches can easily resolve otherwise intractable conflicts of interest.

Attempts to develop this particular kind of cooperation have had to take into account two background factors:

1. The question of whether transatlantic relations could still be seen on both sides of the ocean as transcending the NATO and WTO scenarios in the way provided for by the then New Transatlantic Agenda and its Action Plan.

2. The rate at which it was recognized that the threat to the Atlantic Partnership was no longer so much military as economic. That there is no longer any recognised uniting military threat to bring all the members of the alliance to close ranks on a consistent basis does not, of course, mean that the alliance has no significant purpose. Instead, it implies the need for the constant vigilance and contingency planning that will allow the partners in the alliance to react effectively and efficiently to the emergence of military adventurism.

At the same time, though, we are reminded that nearly all wars have been fought for territorial or economic reasons. Territorial reasons are intrinsically economic, just as the ideological ones are propagandized in order to motivate peoples to get into wars they would otherwise be unwilling to engage in. Whereas, in modern contexts, we can say that the battles being fought are basically economic in character. Globalization is but one, if very important, illustration of this concept. It makes it all the more evident that the U.S. and E.U. economic scenes are interdependent; something that implies the absolute need for cooperation rather than confrontational competition.

In this context maybe we should mention that Europe has a chip on her shoulder. Nobody likes the person who saves her life and Uncle Sam has saved Europe's life twice in the last century. We are not grateful. Nor are we happy to have our viewpoint largely disregarded. We don't like being a minor partner.

\section{The Need for Foreign Exchange Cooperation}

Talk of using cooperative methods sounds like heresy to many advocates of allowing market forces to dictate outcomes. Until, I suggest they reflect deeply on the question of what are the main objectives to be achieved; and ask themselves what is wrong with cooperating with competitors, if in the end everyone benefits and, essentially, if your own side's specific goals are going to be attained - particularly when it looks as if these aims are unlikely to be fulfilled by straightforward competition within the prevailing economic circumstances?

Let's take a closer look, therefore, at what the essential differences between competition and cooperation may be. According to Hayek, the 1974 Viennese Nobel prize-winning political economist whose ideas strongly influenced Lady Thatcher in the middle of her years as Britain's Prime Minister, dynamic competition is a process of discovery. It enables us to open up new frontiers of knowledge. The future shows which new knowledge is useful and which technologies will quickly become obsolete. We have to be ready to welcome the winnowing process, if we wish to realize our full potential for 
economic development. This implies encouraging research, while conserving those national cultural values that are needed to maintain each nation's psychological balance.

Notice that the need to conserve national cultural values is stressed even by this proponent of innovation. So maybe we should remind ourselves of the cultural heritage that continues to be that of the peoples of North America as well as those of Europe. I mean the commonly held values based on Christian precepts that formed the basis for Western civilization.

The Treaty of Rome talked about the uniting of people who share a common culture. In the field of world policy, President Franklin D. Roosevelt dedicated the United States to the policy of the good neighbor; a dedication that, as far as I know, has never been repudiated by any of his successors (Roosevelt, 1933). Surely, therefore, this gives secure grounds for the peoples on both sides of the Atlantic to aim for economic development along parallel paths. This is not, I submit, something that an untrammeled process of globalization is likely to achieve. The ferocity of unbridled competition would provide conditions of life far from the Future Perfect for the majority of the populations of the dominated countries.

Clinging on to outmoded values, of course, is no substitute for building a dynamic future. There is no Past Perfect except in grammar. Nonetheless some values have eternal character. This fact justifies the proposition that optimism about the future may always be welcomed; so long as it is tempered with the desire to hold on to enough of what has lasting value. Hope and the wish to create a better world are not the same as 'damn the torpedoes, full speed ahead'.

Indicating that there is no real dichotomy between competition and cooperation, Herbert Giersch drew the conclusion that the outcome of dynamic competition may often be the form of cooperation that evolves within the pattern of a deepening division of labor (Giersch, 1994). At every level, people want to make use of their comparative advantages. They want to specialize and increase their own particular knowledge and expertise. They are likely to pursue the path of learning by doing. This means that they will require to develop complementary roles with others in their own enterprises as well as with suppliers and customers. This implies cooperation all along the line.

I maintain that cooperation within whole industries is merely an extension of co-operation within one enterprise. The aim is to create a strong base within a competitive world, from which each person or company may realize better results, leading to a better quality of life all round. Each is nonetheless in a position to try to be the best at playing its particular game. A good football team exemplifies what is required: the coordination of efforts to achieve goals, touchdowns or tries, depending on which kind of football is being played. At the same time, it involves doing many things to help the other team members play a better game. As well as jointly taking up the strain when one or more players are beset by problems.

Cooperation tends to centralize many operations, enabling reductions in the costs involved in catering for wider markets. It also generates lower purchasing costs. It is a catalyst for a better world, in which the social advance of many rejects the winner-take-all mentality. It increases cash flows and the multiple effects that these have throughout the area. It is a prime example of what I would call 'harmonic' capitalism. 
As a Christian, I define harmonic capitalism as being at one with a good neighbor mind-set. The harmonic element involves an approach where the central precept will be the optimization, as opposed to the maximization, of profit. In essence this means that the managements of enterprises have always to cater for two sets of interests on an equitable basis. Both the interests of the shareholders and the interests of all the people who collaborate in producing the profits have to be worked for. In a way similar to the approach taken by Zeiss as it transformed itself. In my visualization, this is the approach that will enable the EU to achieve economic development with social cohesion.

Now and then I am asked whether I believe that there is much real hope such a goal being achieved. I can only reply that I believe it to be highly possible. Its achievement depends, principally, on the amount of energy brought to bear by the various individuals who care. The tasks facing an expanding European Union demand the implicit new mindset. It is the only one that adequately answers the challenges of globalization, while availing itself of the benefits that the latter can bring.

As is the case with companies and regional industries - so it is with nations. Competitive pressure constantly bears down on national governments and through them onto regional and local authorities in their dealings with industry, agriculture, viniculture and fisheries. Their true defence lay through the development of complementary, cooperative, regional and national roles.

When more and more countries become integrated into a globalized economy, the greater will be the competitive pressures. A widening EU together with the North American Free Trade Area may currently constitute a large proportion of the world's productive power. The proportion is steadily becoming less predominant. Two thirds of the world's population is to be found in China, India, Pakistan, Indonesia and the rest of South East Asia. At present, the great majority of their peoples subsist on little more than one meal a day. The GNP of their nations is growing apace. Their need to find markets for their goods and services is already compelling.

As the rate of the growth of knowledge accelerates even greater will be the pace of the rate of economic integration. It follows that the EU and the U.S.A. will have to continue along more and more paths of entrepreneurial as well as monetary cooperation. Otherwise, neither of these trading blocs is likely to have enough economic muscle to prosper in what is already a global market for goods, services, information and, of course, finance.

There is one element in particular that will have to provide the scenario within which the two kinds of cooperation can be played out. This is the stability of the relationship between the Euro and the U.S. dollar together with the resulting potential of this relationship as a harmonic factor for international economic development. I don't see that there is any longer any point in discussing whether the U.S. economy will continue to be the engine that pulls the world economy along: or even whether the wider European economy will or is able to substitute for it. We have reached a point where they will have to do it together.

One of the constants of the international money markets is the factor of perception. Fundamentals count for relatively little in the value of a currency. The most important consideration at any given moment is what people believe to be its worth in the short term. 
This means that for a currency relationship to be regarded as stable the movers of money have to be brought to believe that there are strong reasons why there is an endemic, short, middle and long term balance of the flows between the two currencies. Because, whatever the authorities and central bankers say about their respective currencies' merits, the market will place its own interpretation on what is happening in the economies concerned and buy or sell in accordance with this, its own, interpretation. It is against this background that the European Central Bank (the ECB) will have to cooperate with the U.S. Federal Reserve Bank (the Fed), if both are agreed that it will be a good thing to do.

Before we envisage what kinds of moves these two institutions may have to consider taking in order to cooperate to an adequate extent, maybe we have a brief glimpse at a penetrating analysis of currency management. In the early part of a paper delivered by Paul J. Welfens of Potsdam University to Working Group No. 3 of the Fourth ECSA Conference, he stated (Welfens, 1998):

"While flexible exchange rates generally facilitate the control of the money supply and thus are helpful in achieving ECB credibility, one may doubt that the traditional US policy stance would be adequate for Europe. The U.S. largely pursued a benign neglect attitude, according to which market forces should determine the exchange rate, even if this included large deviations from purchasing power parity (PPP). An exception was the Plaza Accord, which sought to moderate a strong dollar appreciation trend that, undoubtedly, was prone to fuel protectionist forces in the U.S.

A strong overvaluation of a currency - misalignment 'from above' - is an implicit subsidy to imports of goods and services and an implicit subsidy to foreign direct investment outflows and net capital exports, respectively. With a given overvaluation there is, of course, no equivalence to a domestic interest rate reduction, since the currency overvaluation concerns only tradables - not the non-tradables sector - and since the mirror effect is an undervaluation of the currency of major partner countries, whose export sector will be stimulated artificially."

Although this citation gives a lot to be absorbed, I have quoted Welfens' ideas because they provide a prelude to consideration about whether the ECB may have pursued a somewhat benign neglect policy towards the roughly $25 \%$ decline in the value of the Euro. It assuredly looked as though this 'de facto' devaluation saved the Eurobloc economy from a recession. At the same time, it can be said that stronger Euro would have complicated many issues for the U.S., particularly when it generated a current account deficit of close to $\$ 400$ billion.

Perhaps, therefore, it wasn't such a bad idea for the ECB to have abstained from intervention in the way that it did. After all, from the viewpoint of an outside central bank looking at the continually mounting U.S. current account deficit, the strength of the dollar did create an undervaluation of the Euro. As a consequence, the Eurobloc's export sector was indeed stimulated at a time when its economic growth was staggering from the blow of the Asian crisis. To have intervened to preserve an artificially, if psychologically significant, exchange rate might easily have nipped Europe's slow economic recovery in the bud.

What about the future scenario now that the M\&A flow appears to have reversed itself a little and the purchase or retention of dollars has slowed? It looks as though the 
esteemed status of the dollar could well diminish, not just because of the some slowdown in the U.S. economy but also because of the unstopped increase of its recurring current account deficits. It is nonetheless still clear that monetary and financial activities on both sides of the Atlantic are interdependent. Probably the best way to keep them in balance is to keep the relationship between the two currencies stabilized in parity with one another.

The ECB will have to resist the temptation to let the chips fall as they may. The Fed will have to be content to keep its interest rates in check. Both institutions will have to design a dynamic of cooperation that allows for the financing and reduction of the U.S. current account deficit as a result of keeping the dollar from becoming overvalued. This could help to moderate FDI outflows and net capital exports. It would not, nor should it, stop the outflows but it could moderate them in such a way as to stabilize the flows between the two currencies. On both sides of the Atlantic policy planners could breathe more easily and devote more of their attention to maintaining the development of the West's economic muscles.

There are at least three ways available to finance and reduce the U.S. current account deficit. In cooperation with the ECB the Fed would probably use a combination of all three. There may well be more ways in which independent central bankers could permute several bilateral agreements so as to ensure their objectives would be achieved. The bankers only have to be sufficiently decided that the success of the operation is paramount. For both Central Banks the operation would be justified as within their remit, because maintaining the two currencies within a narrow range around parity would reduce the threat of either currency area exporting its inflation to the other. And once it is clear to the international community that this form of parity is and will be maintained as their joint goal, the operation will be self-fulfilling.

Corporate finance officers, recognizing that it would no longer matter whether they hold their assets in dollars or euros will be saved the need for hedging between the two currencies. There will also be no point in speculating in that segment of the money markets. The perception all round will be that the relationship between the two currencies has been and will, deliberately, be kept stable. Businessmen will be reassured that they can trade and plan cross-border investments without concern about exchange rate movements. The way will have been opened for development along parallel paths.

\section{Moving to the New Economy - EUnomics, Cohesion and Development}

EUnomics is a term I use to denote the art of devising Economic Strategies for European Cohesion. The practice of this art, as I envisage it, is based on three tenets:

1.Economic Policy is a struggle to find one's way through chaos to a desired objective. It was Schumpeter's view that any policy application has to allow for the unique historic situation in which it is to be applied. The economic situations pertaining in early XXIst century Europe are not only unique but are constantly taking on a new twist. We may well look on them as chaotic.

2. The desired objective is to achieve the cohesion of Europe's widely disparate economies - not through the diktat of uniform policies initiated and administered 
by a centralised bureaucracy. Rather it needs to be achieved through the ever renewed voluntary development of coordinated approaches to dealing with specific situations as they emerge from the morass of previous mistakes.

Self-determining nation states, acting within the principle of subsidiarity, including the provision for proportionality, must not surrender themselves to the mercies of Europe-wide economic or political regimes or they will pay much too high a price. Article 5 of the Treaty of Europe states that any action of the Community shall not go beyond what is necessary to achieve the objectives of the treaty. The idea that the nations can to a great extent govern themselves would be sacrificed and democratic control would be lost, as well as the hope of each nation to apply itself to the resolution of its particular problems in ways acceptable to its own voters.

3. The paramount justification for the development of economic strategies is to raise the potential standard of living for the poorer eighty percent of the population. If this is continuously borne in mind, the strategies will tend to produce an increasingly cohesive effect. Therefore, it is not strategies for economic growth that need to be envisaged. It is strategies for economic development. For economic development to take place the underlying rate of growth has to be self-inducted and self-sustaining, so that changes in the structures of the manufacturing, services and technological industries will yield higher productivity and higher real income per working person. It is therefore reasonable to argue that little or no economic progress may be made when growth occurs without development (Firestone, 1969).

When we agree with and maintain these tenets, it becomes evident that, whereas economic policy has to be concerned with the distribution of resources, in the final analysis economic strategy aims at the most effective use of resources for the welfare of the human beings in a given area.

Economic strategy is, after all and as so often tends to be forgotten, all about making human lives more viable. Riccardo Petrella put the matter eloquently, when he pointed out how 30,000 people a day die for lack of reasonably sanitary water to drink. Human beings, he says, have a right to life.

I beg to go further and say this means that they have a right to struggle to live in dignity. This implies freedom from want. There can be no freedom from want without the chance to earn a competency for a life that is worth while. Ergo, our strategies have to be geared towards economic development. Without it there can be no freedom to develop our humanity, our culture and our spirit.

In the EU, we are trying to construct the most suitable framework within which 27 (and more) countries can make strategic decisions efficiently as well as in relative harmony. Each nation will still have to make such decisions and enact measures to deal with its own particular problems. Structural and Cohesion Funds may help but they do not bring an economy to life with the wave of a wand. Such a result is only achieved through initiative, enterprise and innovation (Bigio, 2002a).

Of the 21-27 million individual Europeans who are without reasonably remunerative jobs, probably 11 million may already be classified as long-term unemployed. As they see things, there appears to be a total lack of measures to prevent their plight and many other similar situations from continuing to result from decisions to merge and/or restructure 
significant numbers of businesses. It is difficult for them to understand why Western-style management has to be to all intents and purposes amoral whenever the maximization of profits is in question.

Surely it isn't necessary to create such havoc. I will seek to show here how a responsible approach to economic development can provide a viable substitute for the harmful competitiveness, which so excessively damages the social infrastructure and cohesion of any community.

Clearly, there is an apparent conflict of priorities between the appreciable reduction of the levels of unemployment and the Lisbon 2000 goal of the EU becoming the most globally competitive economy by around 2010, give or take the odd years of delay.

I suggest that the conflict is only apparent. The aim of considerably reducing levels of unemployment has to be the first priority. A globally competitive economy that fails to deal with such an ulcerated sore fails to address the goal of economic cohesion. By implication, therefore, the EU as a whole should now adjust its strategy regarding competition.

\section{Financial Innovations and Social Responsibility}

The way in which this adjustment has to be done should lie at the crux of EU policy. As I mentioned, the route to economic development runs principally via the exercise of initiative, enterprise and innovation. This by and large means through the setting up of new businesses, which start small and have the prospect of soon becoming medium sized entities. There have to be many such start-ups. There is no economic progress without diversity and the question of whether an enterprise will remain viable is a matter of natural selection.

As is well recognized, innovation is largely dependent on fresh finance. The money that is already employed in the existing circular flow of production, distribution and/or services is not available for new enterprise. As Schumpeter so ably demonstrated, the necessary capital has to be made available from some other source (Schumpeter, 1939). This, basically, is either Venture Capital or credit furnished from national and/or international sources. And, since within a developing nation the availability of spare capital is scarce, it is here that the globalization of finance provides a principal benefit. Without its governing characteristics much Foreign Direct Investment would simply not take place.

I submit that for these reasons EU competition policy could well be adjusted, so as to encourage the emergence, survival and continuous existence of new ventures, protected as they should be from predatory acquisition by large companies that seek to take over successful enterprise.

This kind of protection need not involve putting up barriers to cross-border M \& A. The cause of disastrous mergers or acquisitions resides not in M. \& A. per se but in the acceptance of the fact that administrators, persuaded by investment bankers to take on massive leverage finance, are not held responsible for the inherent mistakes. Sometimes 
these are Horrendously Big Mistakes in judgment of the merits of the financial engineering, for which the exit routes for the bankers are always bound to involve 'restructuring, redundancies and reshuffling of managerial roles'. The more unpleasant aspects of globalization, such as massive dismissals of workers, often more for the sake of expediency than out of real necessity, develop at an alarming rate. Layoffs restrict opportunities in an appalling manner, particularly by virtue of continuing ill-advised management. The capacity of the mega-sized corporation to inflict damage is inflated out of all proportion. The mistakes of one or two administrators affect tens of thousands of people and even whole regional economies. If the effect of such human errors were to have remained confined to the affairs of, say, medium-sized companies, the damage would have been less able to have such far-reaching consequences.

Naturally, those who pay for such changes are always the productive collaborators who, at first, were regarded as key personnel. It is never the financiers, nor the people who made the arrogant self-justified decisions, which all the people below the top of the hierarchy had often recognized as sure to come unstuck.

Moreover, the restructuring processes are all in the name, naturally, of increasing competitiveness. In truth, the financial leveraging is all in the name of greater short term profits - to satisfy analysts and investment organizations. If, instead, the realities of the situation are faced down, the solution will lie with administrators being obliged to devise ways (by dint of their own hard sweat) how to produce what the customers require at attractive, and not necessarily cheaper, prices. This they do by co-opting the collaboration of their colleagues.

Surely, therefore, the aim of a modified Competition Strategy would be rather to avoid having to deal with the more predatory practices indulged in by the larger international corporations. The EU Nations could then, with great advantage to their local economies, adjust their internal economic strategies so as to encourage the envisaged emergence of new ventures, funded principally by Venture Capital, either from within the EU or coming in as FDI.

To ensure that the desired economic development can take place and will have the freedom to prosper, economic strategies could be adjusted either on an EU-wide scale or at will by individual nations or even trans-border regions - within the principle of subsidiarity - by incorporating a specific code of 'cohesion' ethics. This code would enjoin all new enterprises (including those resulting from takeovers or privatization) to be run in line with the aims of what I call Socially Responsible Capital.

I define this as being at one with the Judaeo-Christian good neighbor mindset, which I understand to be shared by most Moslems as well. The good neighbor element involves an approach where the central precept will be the optimization of profit, as opposed to the maximization of shareholder value. In essence, this implies that the level of profit must first be commensurate with the interests of all the people that contribute to the existence and productivity of the respective business. These, quite obviously, do not include overhead expense workers. It is the productive management, technical and sales personnel who have made and continue making useful contributions to the overall success of the enterprise that are the ones who have to be motivated. 
It should go without saying that best efforts are most likely to be forthcoming on a continuing basis, if individuals recognize they will not be tossed aside as soon as they are judged to no longer be of prime benefit to the short-term profitability picture.

The socially responsible use of capital means more than simply seeing to it that the enterprise will be a good corporate citizen, sponsor local projects and contribute to charities (known as Corporate Social Responsibility) as well as, particularly, take all measures to ensure that operations will not adversely affect the environment. Even though the last point - currently characterized as sustainable development - is extremely important to the health of the sources of natural energy underlying human initiative and endeavor, there is, nevertheless, a new and greater implication. It has to do with being part of a fresh approach to business enterprise that I first proposed in 'Taking the Sting out of Globalization for Europe' (Bigio, 2002b). The gist of that paper showed how we may reap the benefits of globalized capitalism even as we mitigate the damage it can do.

\section{Conclusions}

This paper raises issues relevant to the EU-US foreign exchange relationships as well as to the EU competition strategy which should be designed towards achieving not only growth but also economic and social development objectives.

Development along parallel paths brings a specific challenge to relations between the EU and the US. It calls for cooperation at many levels and in many areas. And it calls for mutual respect for their different approaches to resolving economic problems. The EU, for instance, emphasizes the need for social cohesion, whereas the USA still favors pure 'market' capitalism.

The very target of economic development with social cohesion in peace and security complicates the picture for ECOFIN and the ECB. There is a great desire to have the Euro fully respected as the major currency that it is becoming, in that it is a currency that already serves over 350 million people. Yet, in an expanding Europe, providing a single market framework for all of the Central and Eastern European countries during the transformation of their economies means that capitalism without a social conscience just will not serve.

This intrinsic difference of approach itself suggests the strong need for understanding on the part of the US, particularly when it detects the resistance of the EU to what the latter perceives as US dominated processes of globalization. And it presents the EU with its greatest economic challenge so far. The requirement, while still attempting to widen and deepen its union, to restrain its desire to have the strong exchange rate for the Euro that would reflect its hoped for reserve currency status. The challenge, in essence, to restrain this desire and pursue a more essential aim: cooperation to stabilize the relationship between the Euro and the US dollar so that their respective trade areas may develop their economic muscle so as to, jointly, compete in the global marketplace of the twenty-first century.

The concept of Socially Responsible Capital may be instrumental for developing in the EU (and hopefully also outside) the competition strategy which includes economic and 
social development objectives. The paper presents a way of practicing management in harmony also with the best interests of mainly market economies. The tasks facing the EU demand this new approach. The requirements involved in providing a single market framework for so many widely varying national economies imply that capitalism that is not blended with humanity and with social considerations just will not serve.

\section{Appendix}

\section{Practicalities and Practicability}

Much attention is frequently focused on what called productivity imbalances. An early executive summary from The European Commission highlighted an endemic factor in the subparagraph headed 'Strengthening competitiveness and employment creation'. It stated "There are a number of areas in the EU in which structural problems deter investors and inhibit the growth of new economic activities despite reasonable levels of infrastructure and work force skills. These tend to be old industrial regions or those with permanent geographical and other characteristics that constrain development."

The challenge for cohesion policy in these cases is to provide effective support for economic restructuring and for the development of innovative capacity in order to arrest declining competitiveness, falling relative levels of income and employment and depopulation. A failure to do so now will mean the problems are even greater when action is eventually taken."

There can be no correction of the imbalances without increased opportunities for various kinds of productivity. Principally, these opportunities have to come from new 'niche' enterprises. These new businesses are founded by virtue of the initiative of a few of those more adventurous people that are to be seen in every segment of a nation's population. Their diverse initiatives are the very essence underlying the desired economic progress.

Nevertheless, just as there can be no economic progress without diversity, there can be little economic growth without the productivity efforts of the people who accept the risks of joining a new venture. And it is, to a large extent, upon the motivation of these people that the medium and long-term viability of business ventures depends.

I contend that there are literally hundreds of thousands of such people all over Europe, of all ages and degrees of experience and enthusiasm, who are ready and willing to throw themselves wholeheartedly into new venture. Indeed, in such situations it is often found that they contribute more than would normally be expected to the success of enterprises - at whatever level of qualification they can be used.

The young have the enthusiasm, the middle-aged have the know-how, and those who are older and have been made redundant as the result of age-discrimination have vast amounts of experience to make available, especially to start-up companies that may well lack management capability.

In particular, it has to be worth recognizing that, whenever the inevitable process of restructuring takes place, there is a way to bring about a virtuous result from the evils of making personnel redundant. Instead of just shucking off the burden of taking care of the 
erstwhile staff, or passing the task to outplacement consultants, the managers responsible for the restructuring can arrange that the existing enterprise set up new ventures, as separate small businesses.

These ventures it needs to encourage as either management buyouts or completely new initiatives aimed at exploiting a niche in the market. Moreover, although it may choose to back the new enterprises financially, it does not necessarily have to do so, so long as it is prepared to back up with financial guarantees the credit capital that the ventures require.

This kind of process is specially suited to instances of privatization, as was demonstrated in South Wales some forty to fifty years ago, when both the coal and steel industries there had to be closed down. A community of new small businesses was created, located in areas that had previously belonged to the steel company. Financial control and management know-how was furnished and large numbers of people had new hopes for a continuance of contributing to society through their efforts. Of course, not all of them turned out to be successful, but at least they had a far better chance than if they had simply been left to the misery of unemployment.

'But where does the money come from?' is one of the prime questions we have to ask ourselves at every juncture of the processes of fostering cohesion. The recommendations make for good, practical, approaches but who will put up the money involved in each different type of business development?

If I may, I refer you mainly to what I wrote in my essay on Socially Responsible Capital for a number of the answers to questions about how we get the finance involved and how it is channeled. Here, therefore, I will just venture some further thoughts, even though the inherent ideas may not as yet be completely underpinned. The details, I maintain, will always have to be tailored to fit each specific case.

First of all, I fully appreciate the contention that the funds allocated the CAP were intended to help redistribution between regions in France and Germany. Nonetheless, I gathered quite conflicting impressions from some statistics I saw some four and a half months ago, probably in The Economist, but it might have been in the Financial Times. The article in which they were included stated that $72.1 \%$ of the Common Agriculture Policy money goes to large farms - for the large farmers who constitute not more than $13 \%$ of the total of agricultural communities. These $13 \%$ have, of course, very large lobbying power in Paris, Brussels, and various other capitals. The only thing that's going to change this situation is if the European citizens, through the European Parliament, continue to make more and more, and more, fuss until the politicians realize the game is no longer politically viable.

Meanwhile, if just 10\% were to be taken away from the allocations to the CAP and moved into cohesion or structural funds, a lot of the problems that are envisaged - where there may not be enough money to continue the level of regional support -would fade away. There would be sufficient money in the new scenario and there would be no need to raise the level of contribution to the Commission's budget.

If we bring our thinking down to the business level where people start new firms, naturally we have to look for other sources of funding to meet their needs for capital credit capital in this type of case. In this context, I submit that one of the outfits a lot of 
people forget about is the European Investment Bank. The EIB had, I think, 20 billion euros allocated quite recently for a three-year programme into new enterprises. Not all for technology, but assuredly it is supposed to support research and development.

Also for this business level, I can confidently propose that venture capital can be regarded as a promising source of funding. There are a lot of venture capitalists around looking for enterprising new ideas. Venture capital can and does provide an enormous impulse, in partnership with imagination and initiative furnished by entrepreneurial citizens.

Meanwhile, we have to face the fact that there is, naturally, not just a constant rate of change, but a constantly accelerating rate of change; not a rapid rate of change, but changes at near tidal wave velocity.

We have to engineer our way through chaos, we have to engineer our way through change, to engineer our way through an upsetting instability. But it is possible. It is always possible if the political will is there to back those who wish to put their energies into achievement.

\section{Section Three}

These truths make our lives very uncomfortable and deserve prolonged and serious study. Nevertheless, it is not the growth of the unemployment figures alone that has to give us such grounds for deep concern. It is a dimly perceived growth of understanding that our attitudes towards the plight of hunger and deprivation of the poorer two thirds of humanity have to change.

Happily, there is, although we may not fully realize it, an immense development taking place. It represents a new stage in the progress of the human spirit, which perhaps may come to be called the Dawning of True Fellowship.

Perhaps we could interpret this visualization to mean that we are seeing the beginnings of a Compassionate Society. Naturally, this will depend very much on our reactions to the sea change that events force us to face.

\section{Confronting the gloom}

It may well be surprising that, in spite of a plethora of pessimistic punditry each week, there is still an undeniable spirit of hope pervading many Europeans, perhaps especially so in the countries that threw off the yoke of communism. This spirit is the source of a constant energy that amazes not only those who use it but also those whom it confounds. Available to everyone who seeks fair dealings and justice in peaceful solidarity, it requires only the sense of a goal that goes beyond self-aggrandizement.

Thus the multifaceted challenge posed in 1989 -reinforced as it was by the Wahhabi-inspired challenge to the materialistic value system infecting Western society as a whole - now lies redoubled at the feet of all who find their beliefs and culture under threat.

This great challenge defies every Christian, Jewish or Islamic moderate in Europe to pick up the gauntlet. It does not imply violent reaction. Nor does it imply passionate leaps to opposing streams of contention. What it requires is a readiness to change the nature of the business environment that has led to the active alienation of almost two thirds of humanity who have been excluded from a life of dignity. 
What the redoubled challenge demands is that we should each play a part in helping to modify the effects of globalization in those European countries that are seriously subject to the interplay of Foreign Direct Investment. It is not a challenge to make dramatic changes to established ways of transacting business. Instead, it calls on inner strengths and courage. Each one of us will need to take quiet decisions, one step at a time, often on a regular basis.

The aim will be to help produce a gradual transformation in the pattern of New Business Development. A transformation that can only occur like ripples from a pebble cast into a pool.

At this point, even though we could easily assume that we already know the difference between Business Growth and New Business Development, it is as well to remind ourselves of the specific factors involved in each.

Business Growth is relatively easy for us to define. For we see it as resulting from the creation of a greater output of particular goods and services, as and when the demand for them expands. Most corporations, however, are little satisfied by this type of growth. They aim also to achieve new markets through the use of entrepreneurial skills, changes in their corporate structures and the build-up of investment in, or the control of, other businesses.

This kind of achievement of new markets is often called Business Development. For it to occur and endure, it must do more than just induce widespread Business Growth. The growth must also be sustainable on a continuing basis. There is no point in initiating something that will only have a brief flare of profitable activity. The product life has to be long enough to allow for the generation of one or more replacement products.

Put another way, we can say that, if New Business Development is to take place, it should be because one of the prime contributory factors of business expansion is the frequent introduction of new ways to provide what markets require. At the same time, this expansion has to be supported by those changes in corporate structure that sustain higher productivity and higher average real income per person working. Such support is particularly important, because it affects every person who has agreed to play a part in the enterprise and contribute to its productivity. Moreover, entrepreneurs depend on each and every individual who generates added values, however high or lowly their position in the operation of the business.

That brings me to highlight a golden rule that should always be borne in mind by any entrepreneur when making decisions. He or she has to remember that those who help to create extra wealth not only ought to, but have to, receive a commensurate share in it. The practice makes good sense and is perhaps the primary way to ensure the continuance of loyal performance and productivity. Most important of all, it is a rule that fulfils the Judaeo-Christian injunction also mirrored in the Quran: "Love your neighbor as yourself."

As an aside, in case anyone is thinking that religious precepts should not enter into matters of business, I contend that for any believer the 'second commandment' - being as it is like the first, which should be followed with all our heart (emotion), with all our soul (spirit) and with all our might (mental will power) - necessarily has to affect all our attitudes, decisions and behavior. 
Returning to the principle of allotting a 'commensurate share', we can recognize that this implies an obligation to govern our conduct by a crucial maxim - one which shows us the way out of seeming dilemmas while remaining coherent in the way we live and behave. The maxim is that every problem can be better understood when we construct a new representation of it. There are so few coherent choices available between alternate courses of action. Therefore we need to seek, habitually, the knowledge required to define the context for the choice before us.

Defining this context is not as difficult as might seem to be the case. We only have to adhere firmly to our personal sense of the primacy of the value of human individuals, recognizing that these are always more important than the generation of higher profits. If we determine to do this and make our decisions in the light of it, we will maintain humanity in the conduct of our affairs and, step by step, help to transform the environment in which we do business.

Naturally, if we always stick to our principles, our own advancement will now and then be at risk but the results are sure, in the long run, to make us happier to have stood up for our beliefs. As we proceed along our chosen path, we may well receive the kind of energy that so often infuses popular movements.

The quintessential question to consider is: What kind of world we would prefer to live in? Is it one of cut-throat, winner-take-all competition, dominated by global mega-corporations, whose only principle seems to be: 'To be competitive means you have to win market share and maximize profits.'

Or shall we opt for a world where self-development goes hand in hand with a strong sense of social responsibility; a world where the idea of loving our neighbors as ourselves leads to the satisfaction of watching them develop along parallel paths?

\section{References}

Bigio J.E., The Economic Global Challenge Facing an Expanding Europe, address at the conference on: Prospects for EU-US Relationship, Warsaw 2000.

Bigio J.E., Putting on the New Man: The Underlying Implications, Galileu, Vol. VII, No 1, Lisboa 2002.

Bigio J.E., Decision-Making in Polynational Europe, address at the conference on: Europe and the Fifth Enlargement, Warsaw 2002 (a).

Bigio J.E., Taking the Sting Out of Globalization for Europe, [in:] The European Union in the World System Perspective, Polish Institute of International Affairs, Warsaw 2002 (b).

Firestone O.J., Industry and Education: A Century of Canadian Development, Social Science Studies No 5, Ottawa 1969.

Giersch H., Lessons from German Experience - a Keynote Address to Schumpeter Society, 1994.

Rand A., Atlas Shrugged, New York 1957.

Roosevelt F.D., First Inaugural Address, 4 March 1933.

Schumpeter J.A., Business Cycles: A Theoretical, Historical and Statistical Analysis of the Capitalist Process, New York, Toronto, London 1939.

Welfens P., Euro Exchange Policy: Theory, International Integration and Policy Options, Brussels 1998. UNCTAD, World Investment Report: Cross-Border Mergers and Acquisitions and Development, New York and Geneva 2000. 


\section{Reformowanie procesu gospodarowania w Europie}

\section{Streszczenie}

Nieokietznany proces globalizacji, zwłaszcza finansowej, niesie ze sobq zagrożenia dla wzrostu, rozwoju i dobrobytu społecznego. Stanowiq one wyzwanie dla społeczności krajów z gospodarka rynkowq. Można mu sprostać opierajac analizę teoretyczna, jak i praktykę na zmienionych zasadach, normach i procedurach, takich jak wspótpraca, spójność, społeczna odpowiedzialność, sprawiedliwość. W pierwszej części artykułu podejście to odnosi się do europejsko-amerykańskich stosunków walutowych. W drugiej części postuluje się zastosowanie tego podejścia w decyzjach menedżerskich, podporzqdkowanych skadinad wymogom innowacyjności. Jako przydatne narzędzie analizy wprowadza się koncepcje ,społecznie odpowiedzialnego kapitału” (ang. socially responsible capital). Z uwagi na zaawansowanie procesu integracji, kraje Unii Europejskiej sq szczególnie predestynowane do reformowania filozofii i praktyki gospodarowania. 